\title{
DIFFICULTIES OBSERVED DURING LEAN TOOLS TRAINING: INSIGHTS FOR LEADERS
}

\author{
DIFICULDADES OBSERVADAS DURANTE O \\ TREINAMENTO DE FERRAMENTAS LEAN: \\ PERCEPÇÕES PARA LÍDERES
}

\author{
Luis Fernando Torres ${ }^{1}$ \\ Izabela Simon Rampasso ${ }^{1,2}$ \\ Osvaldo Luiz Gonçalves Quelhas ${ }^{3}$ \\ Walter Leal Filho ${ }^{4}$ \\ Vitor William Batista Martins ${ }^{1,5}$ \\ Rosley Anholon ${ }^{1}$
}

\author{
1 Universidade Estadual de Campinas. Campinas, São Paulo, Brazil. \\ 2 PNPD/CAPES Program, Doctoral Program in Sustainable Management Systems, Universidade \\ Federal Fluminense, Brazil. Niterói, Rio de Janeiro, Brazil. \\ 3 Master Program in Management Systems, Doctoral Program in Sustainable Management Systems, \\ Universidade Federal Fluminense. Niterói, Rio de Janeiro, Brazil. \\ 4 Faculty of Life Sciences, Hamburg University of Applied Sciences. Hamburg, Germany. \\ 5 Universidade do Estado do Pará. Belém, Pará, Brazil.
}

\begin{abstract}
Purpose: The lean manufacturing can be an important ally of companies to enhance their competitiveness, since it can support companies to eliminate wastes and continuously improve their processes. In this context, the main purpose of this study was to analyze difficulties observed by operational level employees of auto parts companies during lean tools training.

Design/methodology/approach: A panel of specialists indicated 18 tools required for lean journey training. These tools were used to structure a questionnaire to perform a survey. The survey was conducted with 77 lean training experienced professionals from two auto parts companies. Data collected was analyzed through descriptive statistics and Technique for Order of Preference by Similarity to Ideal Solution (TOPSIS), to rank the tools according to the difficulty levels observed by the respondents.

Findings: In general, operational level employees presented difficulties to understand the concepts of all analyzed tools. Comparatively, Lean Leadership and Constraints Management were those most difficult for them. Originality/value: The results present here can be used by leaders for providing lean training and for academics in futures studies.
\end{abstract}

Keywords: Lean manufacturing; Lean philosophy; Training; Operational level; TOPSIS. 


\section{RESUMO}

Objetivo: A manufatura lean pode ser uma importante aliada das empresas para aumentar a competitividade das mesmas, visto que ela pode dar suporte para as empresas para eliminar desperdícios e melhorar continuamente seus processos. Nesse contexto, o objetivo principal deste estudo foi analisar as dificuldades observadas por funcionários de nível operacional de empresas de autopeças durante o treinamento de ferramentas lean.

Projeto / metodologia / abordagem: Por meio de um painel de especialistas, 18 ferramentas de jornada lean foram identificadas e utilizadas para estruturar um questionário. Uma survey foi realizada com 77 profissionais experientes em treinamento lean. A análise dos dados foi feita por meio da estatística descritiva e da técnica TOPSIS.

Resultados: Em geral, os funcionários de nível operacional apresentaram dificuldades para entender os conceitos de todas as ferramentas analisadas. Comparativamente, Liderança Lean e Gerenciamento de Restrições foram os mais difíceis para eles.

Originalidade / valor: Os resultados aqui apresentados podem ser usados por líderes para fornecer treinamento lean e por acadêmicos em estudos futuros.

Palavras-chave: Manufatura enxuta; Filosofia Lean; Treinamento; Nível operacional; TOPSIS.

\section{INTRODUCTION}

The relevance of production sector for countries economy is recognized in the literature. However, there are several challenges that vary due to markets features. To deal with these challenges, companies need to be flexible and able to adapt their structures (Enke, Glass, and Metternich 2017; Rampasso et al. 2019). In this context, lean manufacturing can be an important ally of companies to enhance their competitiveness, supporting companies to eliminate wastes and continuously improve their processes (Shahin et al. 2016; Yang et al. 2020). However, to achieve lean benefits, companies need to properly train their employees (Lauver et al. 2018).

Despite Lean Manufacturing being a well stablished philosophy and the existence of many research regarding it, there are few studies dedicated to understand professionals that offer training to employees that work on operational level on the tools associated to the referred philosophy. Information regarding the difficulties that these professionals have for training workers in lean manufacturing are of extreme value to transmit knowledge during these trainings and enhance the results obtained from this philosophy implementation. This is the focus of this article, since human resources practices encourage employees to take part in training activities, implementation of tools and decision making, for a better operational performance. Furthermore, according to Womack and Jones (Womack and Jones 2003), the greatest difficulty faced by firms to implement lean philosophy is the lack of understanding the basic fundaments of this philosophy.

Considering these facts, this article aims to assess the perception of experts experienced in lean philosophy training for operational level employees, to identify the main difficulties of these training. Data analysis was made through the TOPSIS (Technique for Order Preference by Similarity to Ideal Solution). The next section is dedicated to the theoretical basis on Lean Manufacturing and Trainings in Lean Manufacturing.

\section{THEORETICAL BACKGROUND}

In this section, it is presented the theoretical background used as basis to develop this study. Concepts about Lean Manufacturing e Training and Lean Thinking are presented in this section. 


\subsection{Lean Manufacturing}

The term Lean Manufacturing stems from a program of the Massachusetts Institute of Technology, in 1979, named International Motor Vehicle Program, that examined the management practices and productivity increasing used by automotive companies in 52 assembly lines, located in 14 countries. This project identified and analyzed the best practices for production processes and generated a set of practices known as Lean Manufacturing. These practices and tools are mostly originated in the Japanese industries and, in particular, in Toyota group (Liker 2005; Womack and Jones 2003).

Ohno (1997) claims that the Toyota Production System, or Lean manufacturing, has its focus on increasing the efficiency of production processes through consistent and complete waste (muda, in japanese) elimination over the whole product chain. These waste can be described as seven types of waste, they are: excessive production; wait; transport; moving; inventory; defects or rework; unnecessary process (Hines, Holweg, and Rich 2004; Karim and Arif-Uz-Zaman 2013; Liker 2005; Maskell and Kennedy 2007; Ohno 1997; Rodríguez et al. 2016; Shingo 1996; Womack and Jones 2003).

The implementation sequence of Lean Manufacturing, in order to reach the lean thinking (continuously minimizing activities that do not add value - wastes), can be represented by five principles, as described in the following (Isack et al. 2018; Womack and Jones 2003): a) specify VALUE to the client; b) identify the VALUE STREAM; c) create a CONTINUOUS FLOW; d) PULL-BASED production; e) Achieve PERFECTION.

Harris et al. (2014) reinforce that, throughout trainings, the instructors should find a way to connect those that are beginning to learn about lean with its tools, in order to allow company's employees to apply their newly acquired knowledge; this, in addition to motivating them, may allow a better learning. Thus, research presenting new information regarding the best practices for lean training are essential. This will be the theme explored on the next section.

\subsection{Training and Lean Thinking}

Introducing lean manufacturing in a workplace is, by definition, to disrupt the current practices and to transform them into practices aligned with the lean manufacturing objectives: waste reduction (Yasukawa, Brown, and Black 2014).

The manufacturing systems, the complex and fast development technologies and the current global business environment demand high competency and continuous learning from all workers. There is a need for a new method to accelerate conversation between knowledge and practice to have an efficient learning, without risk of failure in real life (Smeds 2003). Research about learning define it as a change on individual, due to the interaction between people and their environment. Particularly, the lean model factories concentrate on training managers, executive directors, front line and agents about lean management contents (De Zan et al. 2015). Nogueira, Sousa, and Moreira (2018) and Tortorella and Fogliatto (2017) emphasize the role of leaders during lean implementation.

Sharma, Dixit, and Qadri (2016), in their study, identified 8 critical factors for a successful lean implementation in manufacturing businesses, through the brainstorming technique carried by 5 specialists with broad experience in lean philosophy. The eight critical factors to success were: $5 \mathrm{~S}$, Value Stream Mapping, Just in Time, SMED, Computer Integrated Manufacturing, Concurrent Engineering, ERP and Training. Regarding Training, the authors stress that the resource utilization can be improved through employees training regarding the best ways to perform their tasks. This is applied especially for the adoption of new processes, tools or techniques for a continuous improvement. According to experts' experiences, social and communication competencies facilitate interdisciplinary collaboration, teamwork and information exchange. These competencies can be enhanced through 
employees training (Veile et al. 2019). In addition, according to Stimec (2020), team learning can perform a relevant role in occupational health.

Focusing on training of operational workers, it must be as practical and realistic as possible and based on activities (Gordon et al. 2012; Jeffrey, Hide, and Legg 2010). A significant part of the literature about training has focus on the role of trainers, while the work about learning and learners characteristics has been confined to studies on formal educational environments. Even though training presents a more restrict focus while education presents holistic objectives, there is no reason to presume that the learning styles and approaches of people involved in trainings differ significantly from those involved in educational activities (Jeffrey, Hide, and Legg 2010). According to Etter and Griffin (2011), the training is also needed to answer individual goals. The organizational conflict can arise when company's goals and employees' goals do not coincide. According to House, Spencer, and Pfund (2018), understanding how the participants internalize the concepts of training and translate them in an increased awareness and, later, in action, is fundamental to promote a real change towards workforce diversification. To perform organizational tasks and improve employees' performance, training programs should be projected to create an advantageous situation for organization and workers. Both sides can achieve their objectives if the learning abilities are transferred in an efficient way to the workplace (Awais Bhatti and Kaur 2010).

\section{METHODOLOGICAL PROCEDURES}

The first step of this research was characterized by the literature review for stablishing the theoretical basis. The main scientific basis were used for searching the following terms: lean manufacturing, training, teaching and learning.

A panel of specialists on the subject was used in the second step of this study. This panel was composed of $5 \mathrm{PhDs}$ in production engineering and 5 corporate managers with experience in lean philosophy. This panel identified 18 tools to a lean journey and these tools were used to base a questionnaire used in the survey. It worth mentioning that the 18 lean tools are also aligned with the literature. The panel of specialists was used to define those tools that should be considered in this study. The tools selected by the panel were: $\mathrm{T} 1$ = Constraints Management; $\mathrm{T} 2$ = Lean Leadership; T3 = 5S; $\mathrm{T} 4=7$ Wastes; $\mathrm{T} 5=$ Line Balancing; $\mathrm{T} 6=$ Gemba Walk; $\mathrm{T} 7=$ Continuous Flow; $\mathrm{T} 8=$ Introduction to Lean Manufacturing; T9 = Kaizen; T10 = Total Productive Maintenance; T11=Value Stream Mapping; T12 = Quick Setup; T13 = Takt Time; T14 = Layout Types; T15 = Standard work; T16= Root Cause Analysis (8D, 5 Whys, Andon, PDCA, DMAIC, A3); T17 = Cellular Flow; T18 = Pull System - Kanban. After developing the research instrument, the questionnaire was submitted to a pre-test, as recommended by Hair et al. (2011).

The survey was conducted with 77 lean training experienced professionals that work in Brazil from October/2018 to November/2018. These professionals were selected from two auto parts companies. After answering sample characterization items, the participants analyzed each tool through a range from 1 to 10 ( 1 = operational level workers did not present difficulties or that they presented minimal difficulties to understand the mentioned tool; $10=$ operational level workers showed extreme difficulties to understand the mentioned tool). Through a survey distributed online and in person, 77 answers were received via questionnaires. These respondents have a good experience in providing lean training in businesses of the auto parts sector. The sample was constituted as follows: $28.57 \%$ presented an experience in lean training of up to 5 years, $38.96 \%$ presented an experience varying from 5 to 10 years and, lastly, 32.47\% had more than 10 years of experience. 
Data analysis was made through averages and comparative ordering among the tools studied via Technique for Order of Preference by Similarity to Ideal Solution (TOPSIS). Considering the respondents experience, it was three groups were formed: Group 1: professionals with up to 5 years of experience in lean training, to which was assigned a weight of $20 \%$; Group 2: professionals with experience in lean trainings varying from 5 to 10 years, to which was assigned a weight of 30\%; and Group 3: professionals with more than 10 years of experience in lean trainings, to which was assigned a weight of $50 \%$.

According to Singh et al. (2016), Dandage et al. (2018) and Costa and Duarte Junior (2013), the application of TOPSIS can be described through the steps presented in Figure 1.

Figure 1. Steps conducted for TOPSIS analysis (Costa and Duarte Junior, 2013; Dandage et al., 2018; Singh et al., 2016)
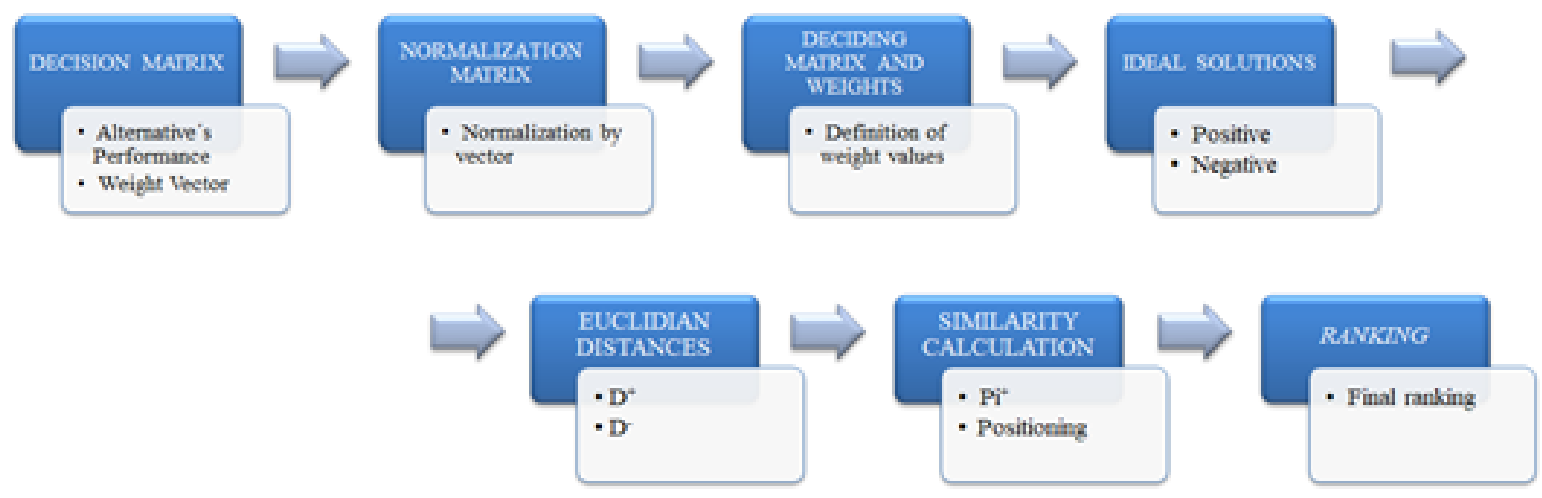

The first step was characterized by Matrix D (Matrix 1) development and the weight vector (Vector 1). The second step was the normalization of Matrix 1 using Equation 1.

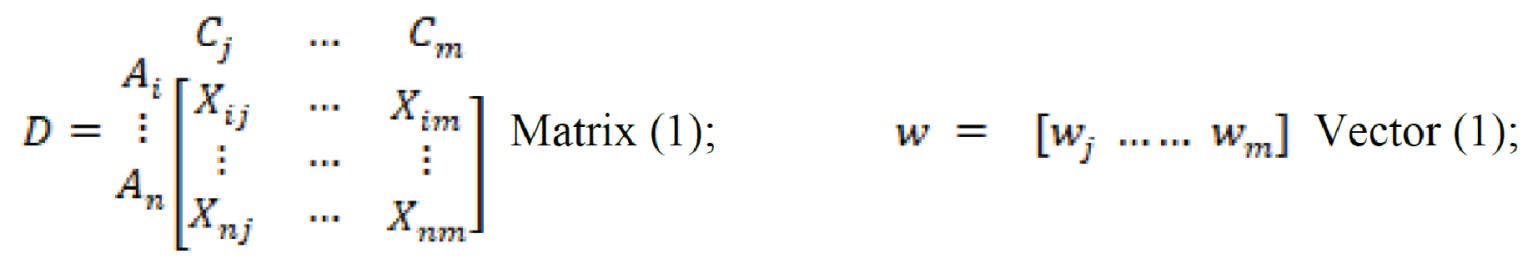

$$
\begin{aligned}
& \overrightarrow{Y_{i j}}=\frac{x_{i j}}{\sqrt{\sum_{i=1}^{m} x_{i j}^{2}}} \quad \text { Equation (1) }
\end{aligned}
$$

In the third step, Matrix $V$ was calculated. It is important to remember that multi-criteria techniques consider different attributes with different degrees of influence on the alternative. Different weights were attributed to each respondents group in line with the experience in lean training, using equation 2.

$$
V_{i j}=w_{i j} \cdot \vec{Y}_{i j} \quad \text { Equation (2) }
$$


In the fourth step it was identified the Ideal Positive Solution and the Ideal Negative Solution for each analyzed criterion. An Ideal Positive Solution (ideal situation) is represented by $\mathrm{S}+$ and an Ideal Negative Solution (anti-ideal situation) is represented by S-, as shown on Equations 3 and 4.

$$
S^{+}=\left\{\max V_{i j}\right\} \quad \text { Equation (3) } ; S^{-}=\left\{\min V_{i j}\right\} \quad \text { Equation (4) }
$$

The fifth step consisted of the calculation of the Euclidean distances ${ }^{1}$ (distances between the ideal positive situation and each alternative, represented by " $D+$ ", and, ideal negative situation and each alternative, represented by "D-") using the Equations 5 and 6.

$$
D_{i}^{+}=\left[\sqrt{\sum_{j=1}^{m}\left(V_{i j}-S_{j}^{+}\right)^{2}}\right] \text { Equation (5) } ; \quad D_{i}^{-}=\left[\sqrt{\sum_{j=1}^{m}\left(V_{i j}-S_{j}^{-}\right)^{2}}\right] \text { Equation (6) }
$$

In the sixth step, the authors of this paper calculated the coefficient Pi+ (Equation 7) that was used as reference for the prioritization or positioning (ranking) of lean tools with higher degree of difficulties for training.

$$
P_{i}^{+}=\frac{D_{i}^{-}}{\left(D_{i}^{+}+D_{i}^{-}\right)} \quad \text { Equation (7) }
$$

In the seventh and last step, the ranking was done, from the alternative in which $\mathrm{Pi}+$ was closer to 1 to the alternative in which $\mathrm{Pi}+$ was to 0 .

\section{RESULTS AND DEBATES}

As mentioned in the previous section, the data collected was analyzed via TOPSIS. The findings obtained in this analysis are presented in this section. In step 1 of TOPSIS, the averages of each group answers were extracted for each lean tool. Table 1 presents the decision matrix " $D$ ". In sequence, the normalization of the matrix " $D$ " was done (see Table 2).

1 For a more detailed explanation on the use of Euclidean distance, see (Hwang and Yoon 1981). 
Table 1. Matrix "D" with averages for each group

\begin{tabular}{|c|c|c|c|c|}
\hline $\begin{array}{c}\text { Variab } \\
\text { le }\end{array}$ & Lean Tool & $\begin{array}{c}\mathbf{1 1 0} \text { years } \\
\mathbf{2 5} \text { answers }\end{array}$ & $\begin{array}{c}\mathbf{6 - 1 0} \text { years } \\
\mathbf{3 0} \text { answers }\end{array}$ & $\begin{array}{c}\mathbf{0 - 5} \text { years } \\
\mathbf{2 2} \text { answers }\end{array}$ \\
\hline T1 & Constraints Management & 7.88000 & 9.23333 & 9.36364 \\
\hline T2 & Lean Leadership & 8.52000 & 8.60000 & 8.50000 \\
\hline T3 & 5S Wastes & 5.04000 & 6.10000 & 6.27273 \\
\hline T4 & Line Balancing & 5.44000 & 6.20000 & 6.22727 \\
\hline T5 & Gemba Walk & 6.80000 & 7.70000 & 7.81818 \\
\hline T6 & Continuous Flow & 6.36000 & 7.26667 & 6.77273 \\
\hline T7 & Introduction to Lean & 5.84000 & 7.96667 & 8.09091 \\
\hline T8 & Manufacturing & 5.16000 & 5.06667 & 5.40909 \\
\hline T9 & Kaizen & 5.36000 & 5.43333 & 5.68182 \\
\hline T10 & Total Productive Maintenance & 6.24000 & 6.96667 & 6.90909 \\
\hline T11 & Value Stream Mapping & 6.04000 & 7.80000 & 8.22727 \\
\hline T12 & Quick Setup & 6.32000 & 7.60000 & 7.27273 \\
\hline T13 & Takt Time & 7.08000 & 7.63333 & 7.86364 \\
\hline T14 & Layout Types & 7.32000 & 7.86667 & 7.54545 \\
\hline T15 & Standard work & 6.32000 & 6.76667 & 7.09091 \\
\hline T16 & Root Cause Analysis & 6.32000 & 6.00000 & 6.27273 \\
\hline T17 & Cellular Flow & 6.32000 & 6.46667 & 7.18182 \\
\hline T18 & Pull System - kanban & 5.56000 & 5.76667 & 6.36364 \\
\hline
\end{tabular}

(Source: Authors)

Table 2. Normalized Matrix

\begin{tabular}{|c|c|c|c|c|}
\hline $\begin{array}{c}\text { Variab } \\
\text { le }\end{array}$ & Lean Tool & $\begin{array}{c}\text { >10 years } \\
\mathbf{2 5} \text { answers }\end{array}$ & $\begin{array}{c}\mathbf{6 - 1 0} \text { years } \\
\mathbf{3 0} \text { answers }\end{array}$ & $\begin{array}{c}\mathbf{0 - 5} \text { years } \\
\mathbf{2 2} \text { answers }\end{array}$ \\
\hline T1 & Constraints Management & 0.28527 & 0.30612 & 0.30527 \\
\hline T2 & Lean Leadership & 0.30844 & 0.28512 & 0.27712 \\
\hline T3 & 5S & 0.18246 & 0.20224 & 0.20450 \\
\hline T4 & 7 Wastes & 0.19694 & 0.20555 & 0.20302 \\
\hline T5 & Line Balancing & 0.24618 & 0.25529 & 0.25489 \\
\hline T6 & Gemba Walk & 0.23025 & 0.24092 & 0.22080 \\
\hline T7 & Continuous Flow & 0.28383 & 0.26413 & 0.26378 \\
\hline T8 & Manufacturing & 0.18680 & 0.16798 & 0.17635 \\
\hline T9 & Kaizen & 0.19404 & 0.18014 & 0.18524 \\
\hline T10 & Total Productive Maintenance & 0.22590 & 0.23097 & 0.22525 \\
\hline T11 & Value Stream Mapping & 0.21866 & 0.25860 & 0.26822 \\
\hline T12 & Quick Setup & 0.22880 & 0.25197 & 0.23710 \\
\hline T13 & Takt Time & 0.25631 & 0.25308 & 0.25637 \\
\hline T14 & Layout Types & 0.26500 & 0.26081 & 0.24600 \\
\hline T15 & Standard work & 0.22880 & 0.22434 & 0.23118 \\
\hline T16 & Root Cause Analysis & 0.22880 & 0.19892 & 0.20450 \\
\hline T17 & Cellular Flow & 0.22880 & 0.21440 & 0.23414 \\
\hline T18 & Pull System - kanban & 0.20129 & 0.19119 & 0.20747 \\
\hline Source: Authors) & & & \\
\hline
\end{tabular}

(Source: Authors) 
With the normalized matrix, the next step (Step 3) consisted of calculating the matrix with the weighted values, considering the attributed weights of each group ( $50 \%$ for Group 3; $30 \%$ for Group 2; $20 \%$ for Group 1). The normalized weighted matrix is shown in Table 3.

Table 3. Weighted normalized matrix

\begin{tabular}{|c|c|c|c|c|}
\hline $\begin{array}{c}\text { Variabl } \\
\text { e }\end{array}$ & Lean Tool & $\mathbf{5 0 \%}$ & $\mathbf{3 0 \%}$ & $\mathbf{2 0 \%}$ \\
\hline T1 & Constraints Management & $\begin{array}{c}\mathbf{1 0} \text { years } \\
\mathbf{2 5} \text { answers }\end{array}$ & $\begin{array}{c}\mathbf{6 - 1 0} \text { years } \\
\mathbf{3 0} \text { answers }\end{array}$ & $\begin{array}{c}\mathbf{0 - 5} \text { years } \\
\mathbf{2 2} \text { answers }\end{array}$ \\
\hline T2 & Lean Leadership & 0.14264 & 0.09184 & 0.06105 \\
\hline T3 & 5S & 0.09123 & 0.08554 & 0.05542 \\
\hline T4 & 7 Wastes & 0.09847 & 0.06167 & 0.04090 \\
\hline T5 & Line Balancing & 0.12309 & 0.07659 & 0.05098 \\
\hline T6 & Gemba Walk & 0.11512 & 0.07228 & 0.04416 \\
\hline T7 & Continuous Flow & 0.14191 & 0.07924 & 0.05276 \\
\hline T8 & Introduction to Lean & 0.09340 & 0.05039 & 0.03527 \\
\hline T9 & Manufacturing & 0.09702 & 0.05404 & 0.03705 \\
\hline T10 & Kotal Productive Maintenance & 0.11295 & 0.06929 & 0.04505 \\
\hline T11 & Value Stream Mapping & 0.10933 & 0.07758 & 0.05364 \\
\hline T12 & Quick Setup & 0.11440 & 0.07559 & 0.04742 \\
\hline T13 & Takt Time & 0.12816 & 0.07592 & 0.05127 \\
\hline T14 & Layout Types & 0.13250 & 0.07824 & 0.04920 \\
\hline T15 & Standard work & 0.11440 & 0.06730 & 0.04624 \\
\hline T16 & Root Cause Analysis & 0.11440 & 0.05968 & 0.04090 \\
\hline T17 & Cellular Flow & 0.11440 & 0.06432 & 0.04683 \\
\hline T18 & Pull System - kanban & 0.10064 & 0.05736 & 0.04149 \\
\hline
\end{tabular}

(Source: Authors)

The next stage consisted of the determining the ideal Positive and Negative solutions for each analyzed criterion (Steps 4). The Ideal Positive Solution (ideal situation) is represented by $\mathrm{S}+$ and the Ideal Negative Solution is represented by S-. It is worth noting that, in this paper, S+ represents the greatest degree of difficulty perceived by the respondents when offering lean tools training and S- the smallest degree of difficulty perceived by the respondents when offering lean tools training. The Table 4 presents the mentioned values.

Table 4. Ideal Positive Solution and Ideal Negative Solution

\begin{tabular}{|c|c|c|c|}
\hline \multirow{2}{*}{$\begin{array}{c}\text { Ideal Positive Solution } \\
\text { and Ideal Negative } \\
\text { Solution }\end{array}$} & $50 \%$ & $30 \%$ & $20 \%$ \\
\hline & $\begin{array}{c}>10 \text { years } \\
25 \text { answers }\end{array}$ & $\begin{array}{l}\text { 6-10 years } \\
30 \text { answers }\end{array}$ & $\begin{array}{c}0-5 \text { years } \\
22 \text { answers }\end{array}$ \\
\hline S+ (greatest difficulty) & 0.15422 & 0.09184 & 0.06105 \\
\hline S- (smallest difficulty) & 0.09123 & 0.05039 & 0.03527 \\
\hline
\end{tabular}

(Source: Authors)

In sequence (Step 5), the Euclidean Distances were calculated between the ideal positive solution and each alternative (represented by $\mathrm{D}+$ ) and between ideal negative solution and each alternative (represented by D-). Results are presented in Table 5. Next, values for the coefficient $\mathrm{Pi}+$ were calculated. 
Table 5. Euclidean Distance between solutions

\begin{tabular}{|c|c|c|c|}
\hline Variable & Lean Tool & Di+ & Di- \\
\hline T1 & Constraints Management & 0.01158 & 0.07089 \\
\hline T2 & Lean Leadership & 0.00845 & 0.07489 \\
\hline T3 & 5S & 0.07311 & 0.01172 \\
\hline T4 & 7 Wastes & 0.06661 & 0.01442 \\
\hline T5 & Gemba Walk & 0.03610 & 0.04413 \\
\hline T6 & Continuous Flow & 0.04687 & 0.03360 \\
\hline T7 & Kanden & 0.01947 & 0.06088 \\
\hline T8 & Introduction to Lean Manufacturing & 0.07798 & 0.00217 \\
\hline T9 & Total Productive Maintenance & 0.07264 & 0.00707 \\
\hline T10 & Value Stream Mapping & 0.04968 & 0.03041 \\
\hline T11 & Quick Setup & 0.04512 & 0.03748 \\
\hline T12 & Takt Time & 0.03207 & 0.03632 \\
\hline T13 & Layout Types & 0.02823 & 0.04766 \\
\hline T14 & Standard work & 0.04906 & 0.05170 \\
\hline T15 & Root Cause Analysis & 0.05501 & 0.03071 \\
\hline T16 & Cellular Flow & 0.05045 & 0.02559 \\
\hline T17 & Pull System - kanban & 0.06665 & 0.02940 \\
\hline T18 & & & 0.01326 \\
\hline
\end{tabular}

(Source: Authors)

Table 6. Values calculated for the coefficient Pi+

\begin{tabular}{|c|c|c|}
\hline Variable & Lean Tool & Pi+ \\
\hline T1 & Constraints Management & 0.85953 \\
\hline T2 & Lean Leadership & 0.89862 \\
\hline T3 & 5S & 0.13815 \\
\hline T4 & L Wastes & 0.17797 \\
\hline T5 & Gemba Walk & 0.55003 \\
\hline T6 & Continuous Flow & 0.41753 \\
\hline T7 & Kaizen & 0.75769 \\
\hline T8 & Introduction to Lean Manufacturing & 0.02710 \\
\hline T9 & Total Productive Maintenance & 0.08872 \\
\hline T10 & Value Stream Mapping & 0.37970 \\
\hline T11 & Tuick Setup & 0.44008 \\
\hline T12 & Takt Time & 0.44601 \\
\hline T13 & Sayout Types & 0.59778 \\
\hline T14 & Root Cause Analysis & 0.64679 \\
\hline T15 & Cellular Flow & 0.38494 \\
\hline T16 & Pull System - Kanban & 0.31747 \\
\hline T17 & & 0.36817 \\
\hline T18 & & 0.16593 \\
\hline
\end{tabular}

(Source: Authors) 
In step 7, the ideal solution is determined by the alternative that is closer to or equal to $\mathrm{Pi}+=1$. In contrast, the alternative that is closer to or equal to $\mathrm{Pi}+=0$ will be an anti-ideal solution. The final product of this analysis is a ranking where the alternatives evaluated are prioritized (Costa and Duarte Junior 2013). Table 7 shows the result.

Table 7. Lean tools position according to the degree of difficulty that operational level workers represent in relation to their comprehension

\begin{tabular}{|c|c|c|}
\hline Order & Tool & Pi+ \\
\hline $\mathbf{1}$ & Lean Leadership & 0.89862 \\
\hline $\mathbf{2}$ & Constraints Management & 0.85953 \\
\hline $\mathbf{3}$ & Continuous Flow & 0.75769 \\
\hline $\mathbf{4}$ & Layout Types & 0.64679 \\
\hline $\mathbf{5}$ & Takt Time & 0.59778 \\
\hline $\mathbf{6}$ & Line Balancing & 0.55003 \\
\hline $\mathbf{7}$ & Quick Setup & 0.44601 \\
\hline $\mathbf{8}$ & Value Stream Mapping & 0.44008 \\
\hline $\mathbf{9}$ & Gemba Walking & 0.41753 \\
\hline $\mathbf{1 0}$ & Standard work & 0.38494 \\
\hline $\mathbf{1 1}$ & Total Productive Maintenance & 0.37970 \\
\hline $\mathbf{1 2}$ & Cellular Flow & 0.36817 \\
\hline $\mathbf{1 3}$ & Root Cause Analysis & 0.31747 \\
\hline $\mathbf{1 4}$ & 7 Wastes & 0.17797 \\
\hline $\mathbf{1 5}$ & Pull System - Kanban & 0.16593 \\
\hline $\mathbf{1 6}$ & 5S & 0.13815 \\
\hline $\mathbf{1 7}$ & Kaizen & 0.08872 \\
\hline $\mathbf{1 8}$ & Introduction to Lean Manufacturing & 0.02710 \\
\hline
\end{tabular}

(Source: Authors)

Analyzing the results, it is possible to establish the following debate. The first item to be commented relates to the averages given by the groups of professionals that offer training in lean production. Regardless of the level of experience, all groups assigned grades over 5.0 to the 18 tools, showing that, in general, difficulties are observed by the operational workers throughout lean trainings. This shows the need for new techniques and methods to disseminate the knowledge.

Another point to stress is the findings obtained through the ordering made by TOPSIS. Comparatively, the lean tool that presents the greatest difficulty, regarding operational workers understanding is related to Lean Leadership, followed by the Constraints Management. The relevance of leadership for lean success is emphasized in Jadhav, Mantha, and Rane (2014), in which authors identified poor leadership as an important barrier for lean implementation. Dombrowski and Mielke (2014) also highlight the importance of leaders for lean to be sustainable throughout the time. Regarding Constraints Management, it is also indicated as a barrier for lean implementation in Jadhav, Mantha, and Rane (2014). It is possible to observed that Lean Leadership and Constraints Management are connected to company boarding management, whose attitude reflect on operational actions. Therefore, the findings presented evidence that a greater participation 
of the boarding management in lean training activities can bring managers and operational level workers closer.

Training is not just about information exchange from trainers to trainees. It requires a symbiotic interaction in which trainers and trainees can learn through exchanges of knowledge, skills and experiences; thus, both groups can be better developed after the mentioned training (Arghode and Wang 2016).

The results show that tools related to the routine of operational level workers of auto parts companies (e.g., 5S, 7 Wastes, Kanban, Total Productive Maintenance, Standard Work, Kaizen) are inserted in this context, because they present a lower difficulty degree for training. The reason for this can be explained by the ease reproducibility of these tools. However, tools that differs from the operational one, related to themes such as planning and logistics presented a greater degree of difficulty for training (Quick Setup, Line Balancing, Takt Time, Layout Types, and Continuous Flow).

Finally, the use of multi-criteria methods (such as TOPSIS) to support the decision making is underlined, which provided a detailed analysis about the alternatives studied. Thus, the information presented previously can be of great value to professionals that offer lean training to perfect their methods of teaching.

\section{CONCLUSIONS}

Based on the perspective of the 77 professionals that offer lean training and participated of this survey, it is possible to establish two main conclusions. The first one is that, in general, operational level workers present difficulties to understand concepts in all analyzed tools; and comparatively, Lean Leadership and Constraints Management are those with the greatest difficult level.

As much as the lean theme has been studied throughout the decades, some issues related to it are still underexplored, as it is the lean training. This research presents some limitations that should be emphasized, such as the sample size and focus on auto part firms, but we believe that the findings reported here can contribute to the literature and the corporate debates.

To solve problems in manufacturing environment and eliminate waste, lean manufacturing uses several tools. The analysis and structuring of a comparative hierarchy of the difficult degree operational level workers for understanding the lean tools regarding are of great value. For industry professionals, these results can be used to improve trainings, paying a special attention on the tools identified as presenting greater levels of difficulty; for researchers, these findings can be used in studies that propose more efficient methods to disseminate this. Those tools that presented greater levels of difficulty should be prioritized in models and roadmaps developed by researchers for developing lean manufacturing implementation. In this line of reasoning, the development of a method for lean training, based on the findings presented can be an interesting research proposal for future studies. In addition, in order to verify the method applicability, trainings could be performed and the findings reported as action research papers. 


\section{REFERENCES}

ARGHODE, VISHAL, AND JIA WANG. 2016. “Exploring Trainers' Engaging Instructional Practices: A Collective Case Study." European Journal of Training and Development 40(2): 111-27. https:// www.emerald.com/insight/content/doi/10.1108/EJTD-04-2015-0033/full/html.

AWAIS BHATTI, MUHAMMAD, AND SHARAN KAUR. 2010. "The Role of Individual and Training Design Factors on Training Transfer." Journal of European Industrial Training 34(7): 656-72. https://www.emerald.com/insight/content/doi/10.1108/03090591011070770/full/html.

COSTA, LEANDRO SANTOS DA, AND ANTONIO MARCOS DUARTE JUNIOR. 2013. "Uma Metodologia Para a Pré-Seleção de Ações Utilizando o Método Multicritério TOPSIS." In XLV Simpósio Brasileiro de Pesquisa Operacional, Natal, 518-29.

DANDAGE, RAHUL, SHANKAR S. MANTHA, AND SANTOSH B. RANE. 2018. "Ranking the Risk Categories in International Projects Using the TOPSIS Method." International Journal of Managing Projects in Business 11(2): 317-31. https://www.emerald.com/insight/content/ doi/10.1108/IJMPB-06-2017-0070/full/html.

DOMBROWSKI, U., AND T. MIELKE. 2014. "Lean Leadership - 15 Rules for a Sustainable Lean Implementation." Procedia CIRP 17: 565-70. https://linkinghub.elsevier.com/retrieve/pii/ S2212827114004259.

ENKE, JUDITH, RUPERT GLASS, AND JOACHIM METTERNICH. 2017. "Introducing a Maturity Model for Learning Factories." Procedia Manufacturing 9: 1-8. http://dx.doi.org/10.1016/j. promfg.2017.04.010.

ETTER, GREGG W., AND RICHARD GRIFFIN. 2011. "In-Service Training of Older Law Enforcement Officers: An Andragogical Argument." Policing 34(2): 233-45.

GORDON, GEOFFREY L. ET AL. 2012. "The Training of Sales Managers: Current Practices." Journal of Business \& Industrial Marketing 27(8): 659-72. https://www.emerald.com/insight/content/ doi/10.1108/08858621211273600/full/html.

HAIR, JOSEPH F. ET AL. 2011. Essentials of Business Research Methods. 2nd ed. Armonk: Routledge.

HARRIS, GREG ET AL. 2014. "Transitioning from Teaching Lean Tools To Teaching Lean Transformation." Journal of Enterprise Transformation 4(3): 191-204. http://www.tandfonline.com/doi/abs/10 $.1080 / 19488289.2014 .930545$.

HINES, PETER, MATTHIAS HOLWEG, AND NICK RICH. 2004. "Learning to Evolve." International Journal of Operations \& Production Management 24(10): 994-1011. https://www.emerald. com/insight/content/doi/10.1108/01443570410558049/full/html.

HOUSE, STEPHANIE C., KIMBERLY C. SPENCER, AND CHRISTINE PFUND. 2018. "Understanding How Diversity Training Impacts Faculty Mentors' Awareness and Behavior." International Journal of Mentoring and Coaching in Education 7(1): 72-86. https://www.emerald.com/ insight/content/doi/10.1108/IJMCE-03-2017-0020/full/html.

HWANG, CHING-LAI, AND KWANGSUN YOON. 1981. 186 Multiple Attribute Decision Making. 
Berlin, Heidelberg: Springer Berlin Heidelberg. http://link.springer.com/10.1007/978-3-64248318-9.

ISACK, HILMA DHIGININA ET AL. 2018. "Exploring the Adoption of Lean Principles in Medical Laboratory Industry." International Journal of Lean Six Sigma 9(1): 133-55. https://www. emerald.com/insight/content/doi/10.1108/IJLSS-02-2017-0017/full/html.

JADHAV, JAGDISH R., SHANKAR S. MANTHA, AND SANTOSH B. RANE. 2014. "Exploring Barriers in Lean Implementation." International Journal of Lean Six Sigma 5(2): 122-48. http://www. emeraldinsight.com/doi/abs/10.1108/IJLSS-12-2012-0014.

JEFFREY, LYNN M., SOPHIE HIDE, AND STEPHEN LEGG. 2010. "Learning Characteristics of Small Business Managers: Principles for Training." Journal of Workplace Learning 22(3): 146-65. https://www.emerald.com/insight/content/doi/10.1108/13665621011028602/full/html.

KARIM, AZHARUL, AND KAZI ARIF-UZ-ZAMAN. 2013. "A Methodology for Effective Implementation of Lean Strategies and Its Performance Evaluation in Manufacturing Organizations." Business Process Management Journal 19(1): 169-96. http://www.scopus.com/inward/record. url?eid=2-s2.0-84873422488\&partnerID=tZOtx3y1.

LAUVER, KRISTY J., ABRAHAM Y. NAHM, BRENT S. OPALL, AND JAMES P. KEYES. 2018. "Becoming Lean: The Employee Perspective." Journal of Business Strategy 39(6): 43-49. https://www. emerald.com/insight/content/doi/10.1108/JBS-04-2017-0041/full/html.

LIKER, J. K. 2005. O Modelo Toyota - 14 Princípios de Gestão Do Maior Fabricante Do Mundo [The Toyota Way: 14 Management Principles from the World's Greatest Manufacturer]. Porto Alegre: Bookman.

MASKELL, BRIAN H., AND FRANCES A. KENNEDY. 2007. "Why Do We Need Lean Accounting and How Does It Work?" Journal of Corporate Accounting \& Finance 18(3): 59-73. http://doi.wiley. com/10.1002/jcaf.20293.

NOGUEIRA, DANIELA MARIA DA COSTA, PAULO S.A. SOUSA, AND MARIA R.A. MOREIRA. 2018. "The Relationship between Leadership Style and the Success of Lean Management Implementation." Leadership \& Organization Development Journal 39(6): 807-24. https:// www.emerald.com/insight/content/doi/10.1108/LODJ-05-2018-0192/full/html.

OHNO, TAICHI. 1997. O Sistema Toyota de Produção: Além Da Produção Em Larga Escala [Toyota Production System - Beyond Large-Scale Production]. Porto Alegre: Bookman.

RAMPASSO, IZABELA S. ET AL. 2019. "Maturity Analysis of Manufacturing Cells." Production Planning \& Contro/ 30(15): 1250-64. https://doi.org/10.1080/09537287.2019.1612108.

RODRÍGUEZ, DENISE, DIRK BUYENS, HENDRIK VAN LANDEGHEM, AND VIRGINIA LASIO. 2016. "Impact of Lean Production on Perceived Job Autonomy and Job Satisfaction: An Experimental Study." Human Factors and Ergonomics in Manufacturing \& Service Industries 26(2): 159-76. http://scholar.google.com/ 


\section{AUTHORS}

\section{Luis Fernando Torres}

Holds B.Sc in Mechanical Engineering - Automation and Systems at São Francisco University (Brazil), MSc. and PhD in Mechanical Engineering at University of Campinas (Brazil).

E-mail: Iftorres00@yahoo.com.br

ORCID: https://orcid.org/0000-0002-5879-9455

\section{Izabela Simon Rampasso}

Holds B.Sc. in Economic Sciences at Pontifical Catholic University of Campinas (Brazil) and M.Sc. and PhD in Mechanical Engineering at University of Campinas (Brazil). Currently, she is postdoctoral researcher at Federal Fluminense University (Brazil) and researcher at University of Campinas.

E-mail: izarampasso@gmail.com

ORCID: https://orcid.org/0000-0003-1633-6628

\section{Osvaldo Luiz Gonçalves Quelhas}

Was president of Production Engineering Brazilian Association (ABEPRO). He is currently coordinator of the Laboratory of Technology, Business and Environment Management (Latec), coordinator of Doctorate Program in Sustainable Management Systems and professor at Fluminense Federal University (Brazil).

E-mail: osvaldoquelhas@id.uff.br

ORCID: https://orcid.org/0000-0001-6816-1677

\section{Walter Leal Filho}

Holds the Chairs of Climate Change Management at the Hamburg University of Applied Sciences (Germany), and Environment and Technology at Manchester Metropolitan University (UK). He directs the Research and Transfer Centre "Sustainability Development and Climate Change Management". He holds various doctoral degrees, such as the degrees of: Philosophy Doctor (PhD), Doctor of Sciences (DSc), Doctor of Philosophy (DPhil), Doctor of Education (DEd), Doctor of Letters (DL) for his works on environment, sustainable development and climate change. He directs the European School of Sustainability Science and Research at the Hamburg University of Applied Sciences, in Germany.

E-mail: walter.leal2@haw-hamburg.de

ORCID: https://orcid.org/0000-0002-1241-5225

\section{Vitor William Batista Martins}

Is currently Professor of the Department of Production Engineering - State University of Pará and PhD candidate in Mechanical Engineering at the University of Campinas. Experienced in Operations Management with focus on Logistics Sytems, Sustainability, Quality Management and Lean Production. He holds B.Sc in Production Engineering at the University of Amazônia (UNAMA) and M.Sc in Civil Engineering at the Federal University of Pará (UFPA).

E-mail: vitor.martins@uepa.br

ORCID: https://orcid.org/0000-0003-4891-8630

\section{Rosley Anholon}

Is professor at University of Campinas, São Paulo, Brazil. He has experience in Sustainable Management System, Education for Sustainable Development and topics related to business management. He holds B.Sc., M.Sc, PhD at University of Campinas and has more than 60 publications in international journals. Currently, he carries out research in partnership with other research groups in Brazil, Germany, Canada and the United Kingdom.

E-mail: rosley@unicamp.br

ORCID: https://orcid.org/0000-0003-3163-6119 


\section{Contribution of authors.}

Every author should account for at least one component of the work. Paper approved for publication need to specify the contribution of every single author.

\begin{tabular}{|c|c|c|c|c|c|c|}
\hline Contribution & [Author 1] & [Author 2] & [Author 3] & [Author 4] & [Author 5] & [Author 6] \\
\hline $\begin{array}{l}\text { 1. Definition of research } \\
\text { problem }\end{array}$ & $\sqrt{ }$ & & & & & $v$ \\
\hline $\begin{array}{l}\text { 2. Development of } \\
\text { hypotheses or research } \\
\text { questions (empirical } \\
\text { studies) }\end{array}$ & $\mathrm{v}$ & & & & & $\checkmark$ \\
\hline $\begin{array}{l}\text { 3. Development of theo- } \\
\text { retical propositions } \\
\text { (theoretical work) }\end{array}$ & v & & & & & 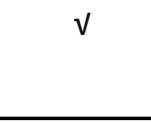 \\
\hline $\begin{array}{l}\text { 4. Theoretical foundation } \\
\text { / Literature review }\end{array}$ & $\sqrt{ }$ & $\sqrt{ }$ & & & $v$ & $v$ \\
\hline $\begin{array}{l}\text { 5. Definition of methodo- } \\
\text { logical procedures }\end{array}$ & v & & & & & $v$ \\
\hline 6. Data collection & v & & & & & \\
\hline 7. Statistical analysis & v & & & & & \\
\hline $\begin{array}{l}\text { 8. Analysis and interpreta- } \\
\text { tion of data }\end{array}$ & $v$ & & $\mathrm{v}$ & $\mathrm{v}$ & & $\mathrm{v}$ \\
\hline $\begin{array}{l}\text { 9. Critical revision of the } \\
\text { manuscript }\end{array}$ & & & v & v & & $v$ \\
\hline 10. Manuscript writing & $\mathrm{v}$ & $\mathrm{v}$ & & & $\mathrm{v}$ & \\
\hline 11. Other (please specify) & & & & & & \\
\hline
\end{tabular}

\section{Conflict of Interest}

The authors have stated that there is no conflict of interest.

\section{Copyrights}

ReA/UFSM owns the copyright to this content.

\section{Plagiarism Check}

The ReA/UFSM maintains the practice of submitting all documents approved for publication to the plagiarism

check, using specific tools, e.g.: CopySpider. 